\title{
Immunologic and Structural Studies of the Lupus/Sjögren's Syndrome Autoantigen, La/SSB, with a Monoclonal Antibody
}

\author{
John B. Harley, Myra O. Rosario, Hajime Yamagata, Owen F. Fox, and Eugen Koren \\ Departments of Medicine and Microbiology, University of Oklahoma Health Sciences Center, and the Arthritis and Immunology \\ Program and Monoclonal Antibody Laboratory of the Oklahoma Medical Research Foundation, Oklahoma City, Oklahoma 73104
}

\begin{abstract}
La/SSB is a small nuclear RNA protein against which precipitating autoantibodies are made in many patients with systemic lupus erythematosus or Sjögren's syndrome. The recent purification of La/SSB has made structural and immunologic studies possible. Consequently, a mouse hybridoma antibody (La1) was raised, after immunization and fusion, that reacted with bovine La/SSB. Results of inhibition tests with tissue extracts and fluorescent antinuclear antibody tests demonstrated that Lal reacted with bovine extracts and cells, but not with those from human, mouse, or rabbit sources. Lal reacted in Western blot and in an adapted anti-La/SSB enzyme-linked immunosorbent assay with only the 41-kD bovine La/SSB peptide and not with the smaller $29-\mathrm{kD}$ bovine La/SSB peptide. RNA gels showed that Lal bound the La/SSB particle that contained the predominant La/SSB RNA species near 90 nucleotides as well as the minor RNA species, both of which were bound by the human autoimmune anti-La/SSB serum. $A$ solid-phase assay for human autoimmune anti-La/SSB antibody using Lal was more sensitive for the detection of human antiLa/SSB than was a comparable assay using purified La/SSB, and showed that anti-La/SSB is present in nearly all Ro/SSA precipitin-positive sera. Thus, this study demonstrates that monoclonal antibody can be raised against La/SSB; that the protein moiety of bovine La/SSB differs from human, mouse, and rabbit at an epitope on the 41-kD La/SSB peptide; that the RNA bound to the Lal-reactive particle was as heterogeneous as that binding the anti-La/SSB autoimmune serum; and that anti-Ro/SSA and anti-La/SSB are closely associated.
\end{abstract}

\section{Introduction}

Autoantibodies reacting with an RNA protein particle now known as $\mathrm{La} / \mathrm{SSB}$ are commonly found in systemic lupus erythematosus (SLE), ${ }^{1}$ Sjögren's syndrome, and subacute cutaneous lupus. The $\mathrm{La} / \mathrm{SSB}$ particle is $\sim 60 \mathrm{kD}$ and is probably composed of a single peptide and a heterogeneous RNA (1,

Address reprint requests to Dr. Harley, Department of Medicine, University of Oklahoma, Health Sciences Center, P.O. Box 26901, Oklahoma City, OK 73104.

Received for publication 4 October 1985

1. Abbreviations used in this paper: ELISA, enzyme-linked immunosorbent assay; MDBK, Madin-Darby bovine kidney; SLE, systemic lupus erythematosus.

J. Clin. Invest.

(c) The American Society for Clinical Investigation, Inc.

0021-9738/85/08/0801/06 $\$ 1.00$

Volume 76, August 1985, 801-806
2). La/SSB RNA appears to be at least initially associated with all RNA polymerase III transcripts (3).

Autoantigen structure and the molecular interactions of autoantibody with autoantigen are avenues of investigation that we hope will lead to better understanding of the immunopathogenic mechanisms of these diseases. As such, monoclonal antibodies to autoimmune antigens have recently become an area of intense interest, especially with respect to SLE (46 ). These reagents have the potential of leading to important insights concerning the structural properties of autoantibodies and autoantigens relevant to the disease process in man as well as in animal models. Monoclonal autoantibodies against DNA have been most intensively studied, though fusions done with the autoimmune mouse strains have also generated monoclonal autoantibodies against ribonucleoprotein and erythrocyte surface antigens $(7,8)$. Our approach has been to attempt to generate monoclonal heteroantibodies against $\mathrm{La} /$ SSB. This study describes such a monoclonal antibody and its application to the analysis of La/SSB and anti-La/SSB.

\section{Methods}

Purification of La/SSB. An affinity chromatography method was used to purify $\mathrm{La} / \mathrm{SSB}$ from calf thymus as described elsewhere (1). The final preparation usually contained the La/SSB RNA and both bovine La/SSB peptides ( 41 and $29 \mathrm{kD}$ ), though occasional preparations contained only the smaller peptide. These materials were used for immunization and analysis.

Immunization. A BALB/c mouse was immunized with $50 \mu \mathrm{g}$ bovine La/SSB in complete Freund's adjuvant by a subcutaneous route. The mouse was boosted with $10 \mu \mathrm{g} \mathrm{La} / \mathrm{SSB}$ suspended in incomplete Freund's adjuvant into the peritoneal cavity. On each of the $3 \mathrm{~d}$ before fusion, the mouse was boosted $(10 \mu \mathrm{g})$ by the peritoneal route, except for the last boost, which was done by the tail vein.

Hybridomas. Spleen cells from the immunized BALB/c mouse were fused with the mouse myeloma cells P3X63-Ag86.5.3 and anti$\mathrm{La} / \mathrm{SSB}$ producing hybridomas were cloned and expanded by the procedure of Galfre and Milstein (9). Five producing wells with anti$\mathrm{La} / \mathrm{SSB}$ activity were found, two of which were successfully cloned.

Mouse anti-La/SSB assay. The enzyme-linked immunosorbent assay (ELISA) technique that we adapted from Engvall and Perlmann (10) for human anti-La/SSB was modified to detect mouse anti-La/ SSB by using a goat anti-mouse IgG conjugate to alkaline phosphatase (Sigma Chemical Co., St. Louis, MO).

Variations in this basic protocol were used in a number of experiments. Preparations containing only the smaller $\mathrm{La} / \mathrm{SSB}$ peptide $(29 \mathrm{kD})$ were also used to determine monoclonal antibody specificities. Preincubation of anti-La/SSB with $\mathrm{La} / \mathrm{SSB}$ or crude concentrated extracts in phosphate-buffered saline of rabbit thymus acetone powder (Pel-Freeze Biologicals, Rogers, AR), human spleen, or calf thymus were carried out for $4 \mathrm{~h}$ at room temperature before being added to the La/SSB-coated plate.

IgG purification and $F\left(a b^{\prime}\right)_{2}$ fragment preparation. IgG was prepared from ascites fluid by Affi-Gel Blue (Bio-Rad Laboratories, Richmond, CA) column chromatography (11). $F\left(a b^{\prime}\right)_{2}$ fragments were generated by pepsin digestion and purified by gel filtration over Sephadex G100 
(Pharmacia Fine Chemicals, Piscataway, NJ) (12). No intact IgG was detected in this $\mathrm{F}\left(\mathrm{ab}^{\prime}\right)_{2}$ preparation.

Western blot and RNA gels. The La/SSB antigenic peptides were detected in Western blot by standard techniques (1). The RNA of the Lal-binding particle was isolated and compared with the human anti$\mathrm{La}$ /SSB binding by the following procedure. An extract of calf thymus was prepared in the presence of ribonuclease inhibitor from human placenta (Sigma Chemical Co.) and concentrated over DE52. The 500 $\mathrm{mM} \mathrm{NaCl}$ eluate was first passed over on anti-Ro/SSA affinity column. This effluent was split into two equal parts. One was passed over a Lal affinity column and the other was passed over an affinity column constructed from an anti-La/SSB that contained human serum. The 3 $\mathrm{M} \mathrm{MgCl} 2$ eluates were dialyzed and concentrated. The nucleic acid was extracted and the RNA was $3^{\prime}$ end-labeled with ${ }^{32} \mathrm{P}$ by previously described methods (13). The labeled RNA was electrophoresed in $7 \mathrm{M}$ urea-10\% polyacrylamide gels and detected by autoradiography.

Fluorescent antinuclear antibody. Cell cultures from different species were used for immunofluorescence. A rabbit corneal epithelial line (SIRC), the National Cancer Tissue Culture (NCTC) clone of the 929 mouse fibroblast line, and the Madin-Darby bovine kidney (MDBK) line (all from American Type Culture Collection, Rockville, MD; CCL60, CCL1, and CCL22, respectively) were grown on slides in RPMI 1640 with $50 \mu \mathrm{g} / \mathrm{ml}$ gentamycin, $5 \mathrm{mM}$ glutamine, and $10 \%$ fetal calf serum. Slides of the human epidermoid carcinoma line, HEp2, were purchased (Breit Laboratories, Inc., West Sacramento, CA). We used standard techniques for immunofluorescence on these substrates, employing goat anti-human fluoresceinated IgG (Breit Laboratories, Inc.) or goat anti-mouse fluoresceinated IgG (Sigma Chemical Co.) as was appropriate for the source of antibody being studied.

Anti-La/SSB ELISA using Lal. The anti-La/SSB monoclonal antibody Lal was adapted to the ELISA technique. Plates were coated with an optimum of $10 \mu \mathrm{g} / \mathrm{ml} \mathrm{Lal}$. Both the $\mathrm{IgG}$ and $\mathrm{F}\left(\mathrm{ab}^{\prime}\right)_{2}$ fragments were used, but the assay that used the $F\left(a b^{\prime}\right)_{2}$ fragments resulted in a lower background and was more sensitive. Then a bovine spleen extract that contained the La/SSB antigen, but which had previously been depleted of Ro/SSA antigen by affinity chromatography, was incubated on the plate at a saturating concentration. After washing with phosphate-buffered saline (PBS)-Tween, the appropriate dilution of human serum was incubated overnight at $4^{\circ} \mathrm{C}$ and then washed with PBS-Tween. A conjugate of goat anti-human IgG to alkaline phosphatase (Sigma Chemical Co.) was incubated on the plate for 4$18 \mathrm{~h}$ at $4^{\circ} \mathrm{C}$, followed by incubation with a substrate solution.

\section{Results}

Of the five uncloned hybridoma cell lines that made anti-La/ SSB, three were available in adequate amounts for initial characterization of species specificity. The anti-bovine La/SSB activity from all three was inhibited by preincubation with only bovine La/SSB as either purified bovine La/SSB, calf thymus extract, or bovine spleen extract. Preincubation with purified human La/SSB, human spleen extract, or rabbit thymus extract did not inhibit the binding of the hybridoma anti-La/SSB antibodies to bovine La/SSB.

Stable clones were produced by only two of the positive hybridomas. Since they both bound only bovine La/SSB, and then only to the larger $41-\mathrm{kD}$ bovine La/SSB peptide (Fig. 1), it was concluded that they were likely to be similarly reactive antibodies and one was chosen for further study and characterization. This monoclonal antibody is an $\operatorname{IgG1}, \kappa$ antibody and has been designated Lal. To confirm that Lal bound only the larger 41-kD La/SSB peptide, an anti-La/SSB ELISA was done using La/SSB preparations composed of either both peptides or of only the smaller $29-\mathrm{kD}$ peptide. Lal bound only the preparation containing the $41-\mathrm{kD} \mathrm{La} / \mathrm{SSB}$ peptide as shown in Table I.

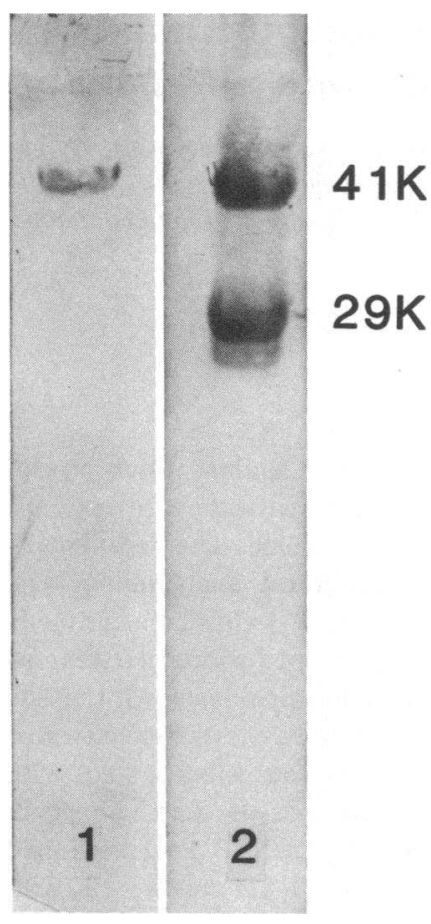

Figure 1. Western blot of a purified $\mathrm{La} / \mathrm{SSB}$ preparation reacting with Lal (lane 1) and with an SLE serum that contains an anti-La/SSB precipitin (lane 2).

To determine whether RNA was precipitated by Lal and to establish that Lal bound only La/SSB, affinity columns of human anti-La/SSB and of Lal were constructed. A thymus extract that had been previously adsorbed with anti-Ro/SSA was passed over the column. The RNA in the Lal and human anti-La/SSB binding material was characterized (Fig. 2). The major La/SSB RNA species found at $\sim 90$ bases (14) was found in both eluates. The patterns of the more minor RNA species bound to the monoclonal Lal and to the polyclonal human anti-La/SSB columns were identical (Fig. 2).

The species specificity of the Lal antibody was further investigated by a fluorescent antinuclear antibody technique. An SLE serum was identified whose immunofluorescent reactivity was blocked on all the substrates used by preincubation with $10 \mu \mathrm{g} / \mathrm{ml}$ bovine La/SSB. Table II shows that Lal ascites fluid is positive on MDBK cells but negative on cells from other species, while the human SLE anti-La/SSB serum is reactive with all the cell lines tested. Lal produced a nuclear

Table I. Binding of Lal and of Human Anti-La/SSB to Different Purified La/SSB Preparations

\begin{tabular}{lll}
\hline & \multicolumn{2}{l}{ La/SSB preparations* } \\
\cline { 2 - 3 } & 41 and $29 \mathrm{kD}$ & $29 \mathrm{kD}$ \\
\hline La1 & 0.562 & 0.000 \\
Human anti-La/SSB & 0.882 & 0.862
\end{tabular}

* The molecular weight of the bovine La/SSB peptides present in the purified $\mathrm{La} / \mathrm{SSB}$ preparations as determined by Western blot analysis are presented. The La/SSB preparations were coated onto an ELISA plate at $1 \mu \mathrm{g} / \mathrm{ml}$.

$¥$ The Lal binding was determined at a $10^{-4}$ dilution of ascites fluid and the human anti-La/SSB was incubated at a $10^{-3}$ dilution $(10,000$ U). Results are expressed as the optical density developed at $405 \mathrm{~nm}$. 


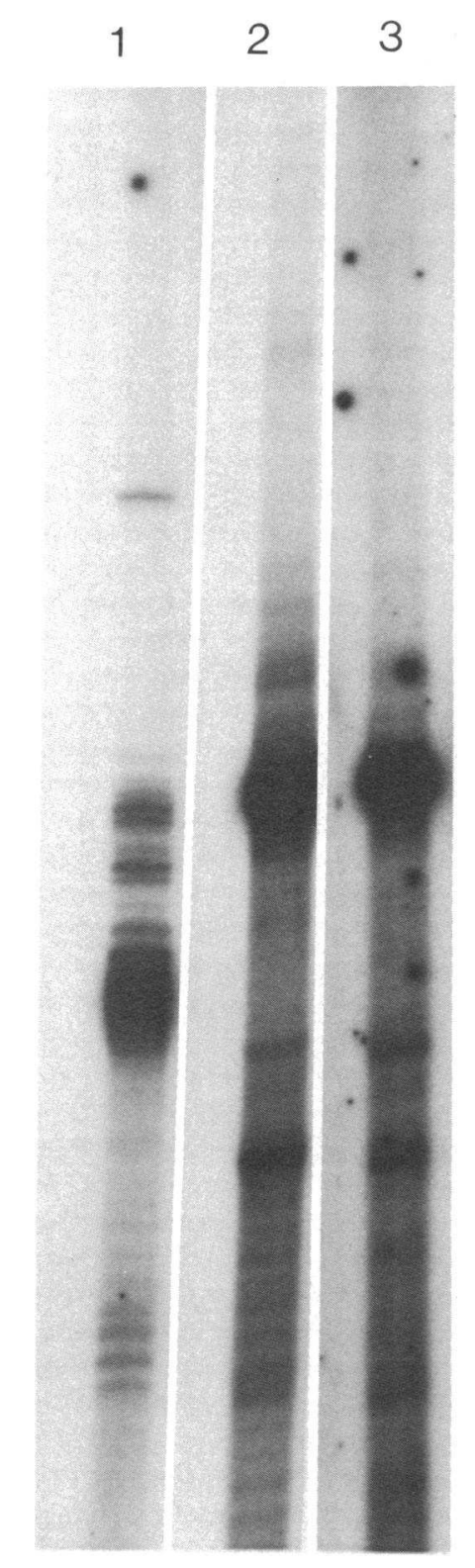

Figure 2. Autoradiographs of RNA species in urea-polyacrylamide gel electrophoresis gels. Transfer RNA control is presented in lane 1. The RNA retained by the human anti-La/ SSB affinity column is in lane 2 and that retained by the $\mathrm{Lal}$ affinity column is in lane 3 .

immunofluorescent pattern and resembled the pattern produced in MDBK by the human serum containing anti-La/SSB (Fig. 3).

Table II. Immunofluorescent Reactivity of LaI on Substrates Derived from Different Species*

\begin{tabular}{lllll} 
Anti-La/SSB source & $\begin{array}{l}\text { HEp-2 } \\
\text { (human) }\end{array}$ & $\begin{array}{l}\text { MDBK } \\
\text { (bovine) }\end{array}$ & $\begin{array}{l}\text { SIRC } \\
\text { (rabbit) }\end{array}$ & $\begin{array}{l}\text { NCTC 929 } \\
\text { (mouse) }\end{array}$ \\
\hline $\begin{array}{l}\text { Human SLE } \\
\text { serum }\end{array}$ & $\underline{1: 3,200}$ & $\underline{1: 3,200}$ & $\frac{1: 800}{<1: 20}$ & $\frac{1: 1,600}{<1: 20}$ \\
\begin{tabular}{c} 
Lal ascites fluid \\
\hline $1: 20$
\end{tabular} & $\underline{1: 25,600}$ & & \\
\hline
\end{tabular}

* Endpoint titers are presented. Endpoint of normal human serum and normal mouse serum controls were $<1: 20$. Underlined positive titers indicate reactivity that could be blocked by preincubation of the serum or ascites fluid with purified bovine $\mathrm{La} / \mathrm{SSB}$ at $10 \mu \mathrm{g} / \mathrm{ml}$.
Lal was used to establish an assay for La/SSB by coating the ELISA plate with Lal and detecting La/SSB bound to Lal with a human $\mathrm{La} / \mathrm{SSB}$ precipitin-positive serum. Heat $\left(45^{\circ} \mathrm{C}\right.$ for $2 \mathrm{~h}$ ) destroyed La/SSB antigen-precipitating activity and was found to decrease $\mathrm{La} / \mathrm{SSB}$ antigen-binding activity by 50 fold (Fig. $4 \mathrm{~A}$ ). In addition, this assay demonstrated that human anti-La/SSB affinity columns removed $>99.9 \%$ of the $\mathrm{La} / \mathrm{SSB}$ antigen in bovine extracts (Fig. $4 \mathrm{~B}$ ). As little as 10 $\mathrm{ng} / \mathrm{ml}$ bovine $\mathrm{La} / \mathrm{SSB}$ was easily detected with this assay (Fig. $4 \mathrm{C}$ ). In other experiments, as little as $1 \mathrm{ng} \mathrm{La/SSB}$ could be detected with longer incubation times. Meanwhile, as much as $10 \mu \mathrm{g} / \mathrm{ml}$ of highly purified Ro/SSA (13) was not detected in this assay procedure, leading to the conclusion that Lal does not bind Ro/SSA.

Finally, a Lal-dependent assay for anti-La/SSB was used to analyze selected sera that had been previously analyzed by an anti-La/SSB assay in which purified $\mathrm{La}$ /SSB was directly adsorbed to the ELISA plate (1). In the new assay, La/SSB from a crude extract was allowed to bind the $F\left(a b^{\prime}\right)_{2}$ fragments of Lal adsorbed to the solid phase. In this new assay, a 10-8 dilution and sometimes a $10^{-9}$ dilution of the standard human anti-La/SSB serum was easily detected in the Lal anti-La/SSB assay, while only a $10^{-7}$ dilution could be detected in the purified $\mathrm{La} / \mathrm{SSB}$ anti-La/SSB assay. In addition to this increased sensitivity, the background binding in normal donors was also substantially lower (Table III). The new assay detected anti$\mathrm{La} / \mathrm{SSB}$ binding over a range of almost $10^{6}$-fold. Also, evidence for anti-La/SSB was found in sera that were Ro/SSA precipitinpositive and La/SSB precipitin-negative. Seven of the eight Ro/SSA precipitin-positive and La/SSB precipitin-negative sera tested had substantial levels of anti-La/SSB-binding activity in this new assay. The remaining serum had a much more modest elevation of anti-La/SSB binding (Table III). Finally, three normal individuals who had been previously shown to have anti-La/SSB in their sera (1) were also shown to have elevated levels of anti-La/SSB by the Lal anti-La/SSB ELISA though their binding levels were comparatively lower than when analyzed by the purified La/SSB anti-La/SSB ELISA assay.

\section{Discussion}

An anti-La/SSB monoclonal heteroantibody has been evaluated which is specific for bovine $\mathrm{La} / \mathrm{SSB}$. It reacts with the larger 41-kD bovine La/SSB peptide but not the smaller 29-kD peptide. Since the $29-\mathrm{kD}$ peptide has been shown to be a degradation product of the $41-\mathrm{kD}$ peptide (15), it can be concluded that the reacting epitope is destroyed or removed by the proteolytic process that generates the smaller peptide. La1 binds $\mathrm{La} / \mathrm{SSB}$ in Western blot analysis and, therefore, must react with the protein portion, since the RNA separates from and migrates to a different part of the gel when La/SSB is subjected to sodium dodecyl sulfate polyacrylamide gel electrophoresis (1). Polyclonal sera have the potential of binding substances other than of the known specificity, in this case $\mathrm{La} / \mathrm{SSB}$. It is therefore reassuring that the same La/SSB RNAs were bound by the Lal monoclonal and the human polyclonal affinity columns. This result strongly suggests that all of the RNA species appreciated in the gel (Fig. 2) are associated with the La/SSB protein. The predominate La/SSB RNA near 90 nucleotides is, most probably, a bovine form of $4.5 \mathrm{~S} \mathrm{La/SSB}$ RNA $(16,17)$. 

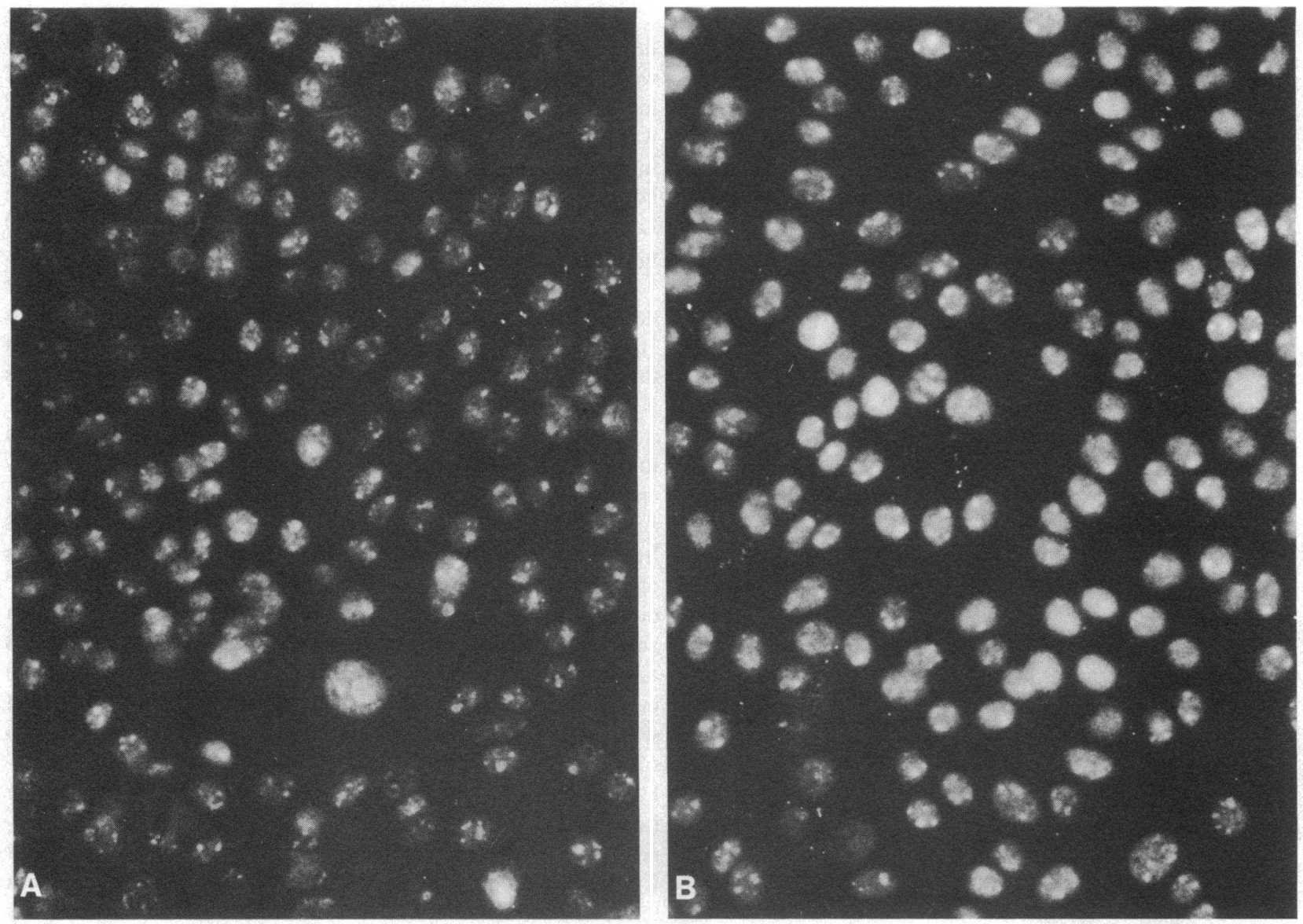

Figure 3. ANA on MDBK cells using the Lal monoclonal antibody $(A)$ and an anti-La/SSB-containing serum $(B)$.

The species specificity of Lal in immunofluorescence (Table II) suggests that $\mathrm{Lal}$ is reacting with a determinant unique to the bovine $\mathrm{La} / \mathrm{SSB}$ molecule. These findings collectively indicate that there is a previously unsuspected heterogeneity between mammalian species in the $\mathrm{La} / \mathrm{SSB}$ protein. In particular, there is an epitope on bovine $\mathrm{La} / \mathrm{SSB}$ that was not found on the $\mathrm{La} / \mathrm{SSB}$ from other species tested.

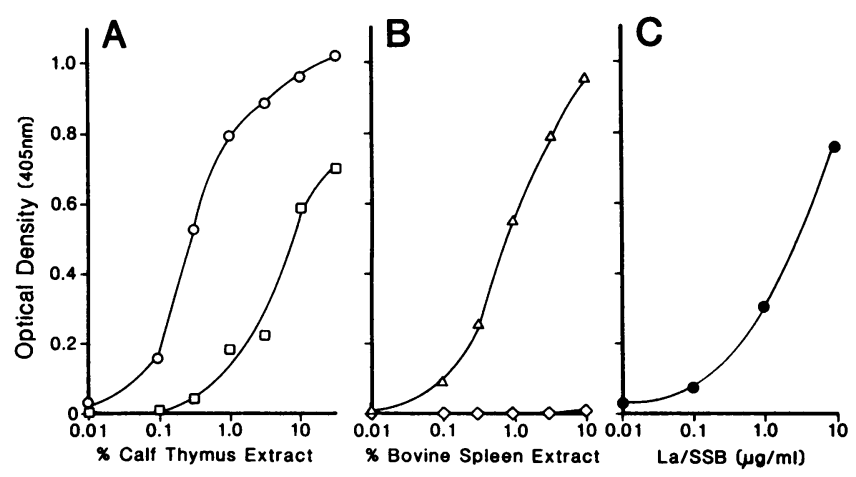

Figure 4. La/SSB content by Lal solid-phase assay. $(A) \mathrm{La} / \mathrm{SSB}$ in calf thymus extract before (O) and after ( $\square$ ) heating to $45^{\circ} \mathrm{C}$ for $2 \mathrm{~h}$. $(B) \mathrm{La} / \mathrm{SSB}$ in bovine spleen extract before $(\Delta)$ and in the effluent after $(\diamond)$ an affinity column made from a human anti-La/SSB serum. (C) Affinity-purified La/SSB (containing both the 29- and 41-kD peptides) binding to $\mathrm{Lal}(\bullet)$.
Previously, we reported an assay for $\mathrm{La} / \mathrm{SSB}$ in which purified $\mathrm{La} / \mathrm{SSB}$ was absorbed to the solid phase (1). This assay was $\sim 1,000$-fold more sensitive for anti-La/SSB than Ouchterlony gel double diffusion and was applied to the analysis of SLE and normal sera. A direct comparison of the purified La/ SSB ELISA with a precipitation technique showed good quantitative fidelity between methods (18). It was found that $>50 \%$ of the Ro/SSA precipitin-positive and La/SSB precipitin-negative sera had substantial levels of anti-La/SSB. The incidence of anti-La/SSB in SLE patients who were Sm or nuclear ribonucleoprotein precipitin-positive and La/SSB precipitinnegative, however, did not differ from a normal control population. Anti-La/SSB-binding activity was found in $7.5 \%$ of the normal controls. That this activity was true anti-La/ SSB autoantibody was established by inhibition with human $\mathrm{La} / \mathrm{SSB}$, by immunoblotting of the La/SSB peptides, and by the demonstration that binding resided in the $F\left(a b^{\prime}\right)_{2}$ fragments of their IgG fraction (1).

Lal that is available in relatively large amounts makes possible, not only a sensitive assay for $\mathrm{La} / \mathrm{SSB}$, but also a very sensitive assay for anti-La/SSB. In this new assay, La/SSB is bound to Lal that had previously been adsorbed to the solid phase. In contrast, the assay that uses purified $\mathrm{La} / \mathrm{SSB}$ adsorbed to the solid phase (1) is less sensitive and demonstrates more variation. Sensitivity of the new assay might also be increased because Lal can theoretically bind two bovine La/SSB molecules, thereby as much as doubling the relative amount of La/ 
Table III. Lal ELISA for Anti-La/SSB

\begin{tabular}{lllll}
\hline & \multicolumn{2}{l}{ Precipitins } & & \\
\cline { 2 - 3 } Category & Ro/SSA & La/SSB & & $\begin{array}{l}\text { Purified } \\
\text { La/SSB ELISA }\end{array}$ \\
\hline & & $(U)^{*}$ & Lal ELISA
\end{tabular}

\begin{tabular}{cccrr}
\multicolumn{2}{c}{ Normal donorsł } & & & \\
1 & - & - & 224 & 52 \\
2 & - & - & 175 & 29 \\
3 & - & - & 69 & 32 \\
4 & - & - & 443 & 42 \\
5 & - & - & 79 & 23 \\
6 & - & - & 683 & 26 \\
7 & - & - & 29 & 120 \\
8 & - & - & 845 & 32 \\
9 & - & - & 30 & 33 \\
10 & - & - & 444 & 112
\end{tabular}

Ro/SSA and La/SSB precipitin-positive SLE patients

$\begin{array}{rrrrr}1 & + & + & 13,800,000 & 20,100,000 \\ 2 & + & + & 13,500,000 & 22,900,000 \\ 3 & + & + & 8,300,000 & 14,300,000 \\ 4 & + & + & 6,900,000 & 4,830,000\end{array}$

Ro/SSA precipitin-positive and purified La/SSB ELISA-positive SLE patients

$\begin{array}{lllll}1 & + & - & 29,500 & 155,000 \\ 2 & + & - & 40,000 & 756,000 \\ 3 & + & - & 45,000 & 151,000\end{array}$

Ro/SSA precipitin-positive and La/SSB ELISA-negative SLE patients

$\begin{array}{rrrrr}1 & + & - & 158 & 237 \\ 2 & + & - & 409 & 912 \\ 3 & + & - & 120 & 20,400 \\ 4 & + & - & 640 & 3,020 \\ 5 & + & - & 120 & 1,260\end{array}$

Purified La/SSB ELISA-positive normal donors

$\begin{array}{rrrrr}1 & - & - & 7,200 & 195 \\ 2 & - & - & 22,000 & 3,160 \\ 3 & - & - & 21,000 & 1,820\end{array}$

* $1 \mathrm{U}$ is the binding present in $10^{-7}$ of a standard $\mathrm{La} / \mathrm{SSB}$ precipitinpositive serum.

$\ddagger$ Log average backgrounds in the purified La/SSB ELISA and the La1 ELISA were 171 and $42 \mathrm{U}$, respectively, with upper limits of 2,053 and $135 \mathrm{U}(+2 \mathrm{SD})$, respectively.

SSB on the ELISA plate. Lal also probably binds an epitope of bovine La/SSB that does not compete with human anti-La/ SSB autoantibody and, hence, Lal may orient La/SSB on the ELISA plate for maximum reactivity with anti-La/SSB autoantibody. In addition, we have observed that IgG binds to the plate more reproducibly than does the RNA protein particle. Finally, differences in the treatment of the La/SSB used in the two assays may explain differences in sensitivity. Affinity purification of $\mathrm{La} / \mathrm{SSB}$ requires exposure to denaturing solutions (here, $3 \mathrm{M} \mathrm{MgCl}_{2}$ ), while the $\mathrm{La} / \mathrm{SSB}$ removed from the crude extract by Lal has not been exposed to such extreme conditions. The $\mathrm{La} / \mathrm{SSB}$ in the Lal assay may have a more native structure and, therefore, be more reactive with autoantibody.

The results with the previous solid-phase assay for anti-
La/SSB using purified La/SSB (1) were confirmed and extended with the new, more sensitive assay using Lal (Table III). The Lal assay repeats the hierarchy found in the purified La/SSB assay, but certain differences are evident. The anti-La/SSB binding levels are higher in all the Ro/SSA precipitin-positive and $\mathrm{La} / \mathrm{SSB}$ precipitin-negative sera relative to findings in the purified $\mathrm{La} / \mathrm{SSB}$ anti-La/SSB assay. Indeed, all of these sera are positive for anti-La/SSB binding activity in the Lal assay when compared with the 10 anti-La/SSB-negative normal donors, though serum 1 of this group approaches the level found in the anti-La/SSB-negative normal donors. Furthermore, normal sera in which anti-La/SSB antibody had been previously demonstrated (1) remained substantially above the 10 negative control sera, but had relatively less anti-La/SSB binding activity in the Lal assay. Perhaps the previously appreciated lower affinity for La/SSB in these sera when compared with anti-La/SSB precipitin-positive patients (1) is the basis for this observation. In any case, this new assay dramatically increases our capacity to distinguish patient sera from normal sera. Since it does not require the purification of antigen, large scale clinical application would be feasible.

The generation of this monoclonal antibody suggests that $\mathrm{La} / \mathrm{SSB}$ is antigenic in mice. The monoclonals generated by this protocol appear to be species specific, reacting only with bovine La/SSB. None of the findings of this study support the notion that $\mathrm{La} / \mathrm{SSB}$ has unusual antigenic properties in these circumstances. Other similar studies on this and the other extractable nuclear autoantigens should generate powerful tools with which to dissect the immune response and its dysregulation in SLE, Sjögren's syndrome, and related disorders.

\section{Acknowledgments}

The authors appreciate the encouragement and critical evaluation of this study by Dr. Morris Reichlin and the technical assistance of Kimberley K. Gaither and Bobbye Hill.

This study was supported in part by National Institutes of Health grants AM-31133 and BSRG-S07-05538-21 and a grant from the Oklahoma Chapter of the Arthritis Foundation. M. O. Rosario was a Graduate Professional Opportunities Program Fellow and a recipient of a Gina Finzi summer fellowship from the Lupus Society of America. J. B. Harley is a recipient of an Arthritis Investigator Award from the Arthritis Foundation.

\section{References}

1. Harley, J. B., H. Yamagata, and M. Reichlin. 1984. Anti-La/ SSB antibody is present in some normal sera and is coincident with anti-Ro/SSA precipitins in systemic lupus erythematosus. J. Rheumatol. 11:309-314.

2. Lerner, M. R., and J. A. Steitz. 1981. Snurps and scyrps. Cell. 25:298-301.

3. Rinke, J., and J. A. Steitz. 1982. Precursor molecules of both human 5S ribosomal RNA and transfer RNAs are bound by a cellular protein reactive with anti-La lupus antibodies. Cell. 29:149-159.

4. Andrzejewski, C., Jr., B. D. Stollar, T. M. Lalor, and R. S. Schwartz. 1980. Hybridoma autoantibodies to DNA. J. Immunol. 124: 1499-1502.

5. Hahn, B. H., F. Ebling, S. Freeman, B. Clevinger, and J. Davie. 1980. Production of monoclonal murine antibodies to DNA by somatic cell hybrids. Arthritis Rheum. 23:942-945.

6. Eilat, D. 1982. Monoclonal autoantibodies: an approach to studying autoimmune disease. Mol. Immunol. 19:943-955. 
7. DeHeer, D. H., J. M. Pages, and A. E. Bussard. 1980. Specificity of antierythrocyte autoantibodies secreted by a NZB-derived hybridoma and NZB peritoneal cells. Cell. Immunol. 49:135-141.

8. Lerner, E. A., M. R. Lerner, C. A. Janeway, Jr., and J. A. Steitz. 1981. Monoclonal antibodies to nucleic acid-containing cellular constituents: probes for molecular biology and autoimmune disease. Proc. Natl. Acad. Sci. USA. 78:2737-2741.

9. Galfre, G., and C. Milstein. 1981. Preparation of monoclonal antibodies: strategies and procedures. Methods Enzymol. 73:3-46.

10. Engvall, E., and P. Perlmann. 1971. Enzyme-linked immunosorbent assay (ELISA). Quantitative assay of immunoglobulin G. Immunochemistry. 8:871-874.

11. Brack, C., D. Portetelle, C. Glineur, and A. Bolleu. 1982. Onestep purification of mouse monoclonal antibodies from ascitic fluid by DEAE Affi-Gel Blue chromatography. J. Immunol. Methods. 53:313319.

12. Campbell, D. H., J. S. Garvey, N. E. Cremer, and D. H. Sussdorf. 1970. Methods Immunol. 224-234.

13. Yamagata, H., J. B. Harley, and M. Reichlin. 1984. Molecular properties of the Ro/SSA antigen and enzyme-linked immunosorbent assay for quantitation of antibody. J. Clin. Invest. 74:625-633.

14. Lerner, M. R., J. R. Boyle, J. A. Hardin, and J. A. Steitz. 1981. Two novel classes of small ribonucleoproteins detected by antibodies associated with systemic lupus erythematosus. Science (Wash. DC). 211:400-402.

15. Venables, P. J. W., P. R. Smith, and N. Maini. 1983. Purification and characterization of the Sjögren's Syndrome A and B antigens. Clin. Exp. Immunol. 54:731-738.

16. Ro-Choi, T. S., R. Reddy, D. Henning, T. Takano, C. W. Taylor, and H. Busch. 1972. Nucleotide sequence of $4.5 \mathrm{~S}$ ribonucleic acid ${ }_{1}$ of Novikoff hepatoma cell nuclei. J. Biol. Chem. 247:3205-3222.

17. Harada, F., and N. Kato. 1980. Nucleotide sequences of 4.5S RNAs associated with poly(A)-containing RNAs of mouse and hamster cells. Nucleic Acids Res. 8:1273-1285.

18. Harley, J. B. 1985. Autoantibodies in Sjögren's syndrome: comparison autoantibody determination methods show that antinuclear antibody and rheumatoid factor are associated with Ro/SSA precipitin formation. Protides Biol. Fluids. In press. 